\title{
Protection and Risk for Different School Stress Trajectories
}

\author{
Marta Regina Gonçalves Correia-Zanini ${ }^{1}$ \\ Sonia Regina Loureiro ${ }^{2}$ \\ Edna Maria Marturano ${ }^{2}$
}

\begin{abstract}
The study of chronic stress, potentially harmful to development, resents the focus of research on modal trends, not discriminating individual trajectories of chronicity. This study aimed to associate groups differentiated by the trajectory of stress, in children from the 1st to the 3rd year of Elementary School - Without Stress, Acute Stress and Chronic Stress, to the variables of protection or risk of the child and the school itself. One hundred and eleven students (56 boys) participated in the Child Stress Scale, Provinha Brasil, School Stressors Inventory and Social Skills Rating System - Teachers. Early childhood education, the Basic Education Index and the location of the school were considered. Comparison and prediction analyses were performed. Results indicated worse performance and greater perception of stressors in the group with chronic stress. Externalizing behavior, performance stressors and less permanence in Early Childhood Education contribute to chronicity. The focus on trajectories highlighted the vulnerability of chronically stressed children.
\end{abstract}

Keywords: stress, risk factors, elementary school students

\section{Proteção e Risco para Diferentes Trajetórias de Estresse de Escolares}

Resumo: O estudo do estresse crônico, potencialmente prejudicial ao desenvolvimento, ressente-se do foco das pesquisas em tendências modais, não discriminando trajetórias individuais de cronicidade. O presente estudo teve como objetivo associar grupos diferenciados pela trajetória de estresse, de crianças do $1^{\mathrm{o}}$ ao $3^{\circ}$ ano do Ensino Fundamental - Sem Estresse, Estresse Pontual e Estresse Crônico, à variáveis de proteção ou de risco da própria criança e da escola. Participaram 111 alunos (56 meninos) avaliados pela Escala de Estresse Infantil, Provinha Brasil, Inventário de Estressores Escolares e Social Skills Rating System - Professores. A Educação Infantil, o Índice da Educação Básica e a localização da escola foram considerados. Análises de comparação e de predição foram realizadas. Os resultados indicaram pior desempenho e maior percepção de estressores no grupo com estresse crônico. Comportamento externalizante, estressores do desempenho e menor permanência na Educação Infantil contribuem para a cronicidade. $\mathrm{O}$ foco nas trajetórias ressaltou a vulnerabilidade das crianças cronicamente estressadas.

Palavras-chave: stress, fatores de risco, estudantes de ensino fundamental

\section{Protección y Riesgo en Diferentes Trayectorias de Estrés de Escolares}

\begin{abstract}
Resumen: Los estudios acerca del estrés crónico potencialmente dañino para el desarrollo se basan en investigaciones enfocadas en tendencias modales, sin discriminar las trayectorias individuales de la cronicidad. El presente estudio tuvo como objetivo asociar los grupos diferenciados por la trayectoria de estrés en niños del $1 .^{\circ}$ al $3 .^{\circ}$ grado de la primaria - Sin estrés, Estrés puntual y Estrés crónico, con las variables de protección o de riesgo del niño y de la escuela. Se evaluaron a 111 alumnos (56 chicos) utilizando la Escala de Estrés Infantil, la Provinha Brasil, el Sistema de Inventario de Estrés de Escolares y el Social Skills Rating System, Maestros. Se consideraron la Educación de la primera infancia, el Índice de educación básica y la ubicación de la escuela. Se hizo el análisis de comparación y de predicción. Los resultados indicaron un peor rendimiento y una mayor percepción de estresores en el grupo con estrés crónico. El comportamiento externo, los factores estresantes del rendimiento y la menor permanencia en la educación de la primera infancia contribuyen a la cronicidad. El enfoque en las trayectorias destaca la vulnerabilidad de los niños con estrés crónico.
\end{abstract}

Palabras clave: estrés, factores de riesgo, alumnos de la primaria

${ }^{1}$ Centro Universitário das Faculdades Associadas de Ensino, São João da Boa Vista-SP, Brazil

${ }^{2}$ Universidade de São Paulo, Ribeirão Preto-SP, Brazil

Support: CNPQ (Process PDJ 15750/2017-0) and FAPESP PD (Process no. 2014/01478-4). Correspondence address: Marta Regina Gonçalves Correia Zanini. Centro Universitário das Faculdades Associadas de Ensino. Largo Engenheiro Paulo de Almeida Sandeville, $n^{\circ} 15$, São João da Boa Vista-SP, Brazil. CEP 13.870-377. E-mail: psico_marta@yahoo.com.br
There are indications in the literature that some variables can modify, improve or alter the response of individuals to hostile environments that predispose to maladaptive consequences, that is, they are protective factors, while others are associated with a high probability of occurrence of negative or undesirable results, being considered as risk factors (Reppold, Pacheco, Bardagi, \& Hutz, 2002). This article focuses on the outcome of differentiated stress 
trajectories, resulting from three assessments of stress symptoms of children attending the beginning of elementary school, and seeks to verify their association with protective and risk factors for development, with the expectation that the impact of trajectories be different depending on the intensity and duration of stress symptoms.

Stress is considered to be a natural reaction of the organism manifested by physiological and psychological changes in the face of irritating, threatening or pleasurable stimuli, which may occur due to changes in the environment and/or activities, or even due to personal characteristics, emotions or beliefs (Lipp, 2014). However, if such manifestation is intense or prolonged, it can lead the child to illness, compromising his/her development (Lipp \& Lucrelli, 2008).

The level or intensity of stress is related to three factors. The first refers to the quality or nature of the stressor event, that is, if it is an internal or external source, the second, to the magnitude of the stressor source, and the third, to the level of demand for the individual (Byrne, Thomas, Burchell, Olive, $\&$ Mirabito, 2011). Thus, it is understood that the same stimulus can be an intense source of stress for one person, moderate for another and not for a third person. Therefore, studies that consider personal and contextual aspects when it comes to stress are important.

Based on the survey of studies on the development of schoolchildren, it is understood that some personal variables are important, among them the indicators of school achievement, such as performance measured by objective tests, social skills and behavioral problems. In terms of context, the schools, assessed by indicators of their quality and location, are also relevant variables in studies that occur in the context of schooling.

With regard to performance, in the national literature, there are indications of its negative relationship with the stress of children in the 1st year of elementary school (Crepaldi, Correia-Zanini, \& Marturano, 2017; TrivellatoFerrreira \& Marturano, 2008). Similar results were found by Romanholo et al. (2017), in a cross-sectional study with children aged five to twelve. In international studies, stress was a predictor of the performance of American adolescents, three years after their evaluation (Kaplan, Liu, \& Kaplan, 2005), and in China, stress in the interaction with the teacher predicted the drop in academic performance at the end of the year, in high school teenagers ( $\mathrm{Liu} \& \mathrm{Lu}, 2011$ ).

Apparently, social skills can protect against symptoms of stress, as suggested by data reported by Crepaldi et al. (2017) who identified greater social repertoire in 2nd year students without stress. The stress prediction model of elementary school students developed by Sbaraini and Scherman (2008) identified social skills as one of the significant variables. The study carried out by Oberle (2018), with students from Canadian schools, attending the 4th to 7 th grades of elementary school, found a significant and inverse association of stress measured through capillary cortisol, with perspective taking and prosocial behaviors.

On the contrary, inhibition and difficulty in relating, typical behaviors of internalizing problems, seem to constitute a risk for stress (Cairney, Rigoli, \& Piek, 2013; Yuan, Zhang, \& Fu, 2017), especially for boys (Crepaldi et al., 2017), as well as externalizing behavior problems (Crepaldi et al., 2017; Stasiak \& Weber, 2013).

The school context can be a source of stress, as it presents demands that are seen as burden by children, generating tensions related to academic issues (Escobar et al., 2013) and to relationships with teachers, peers and parents (Stasiak \& Weber, 2013). In the longitudinal study by Byrne et al. (2011), with children aged 7-8, the impact of school stressors was a predictor of anxiety two years later.

In the stress prevention, previous experiences, such as access to early childhood education, can act as a protective factor; the frequency of attendance at this teaching modality is also a positive influence (Trivellato-Ferreira \& Marturano, 2008).

The quality of the school can also be a protective factor against stress. In Brazil, the Basic Education Development Index - IDEB (National Institute of Educational Studies and Research Anísio Teixeira [INEP], 2018) is the official measure of the quality of Basic Education, derived from two factors: school flow and averages of performance of students in assessments. On a 0 to 10 scale, schools with values equal to or greater than six are considered of quality. The school location is another quality indicator, as it contains the population characteristics, the neighborhood structure and the socioeconomic level of its residents, variables that can have an impact on school performance (Almeida, 2017). A recent study carried out in the Netherlands by Vliegenthart et al. (2016) corroborated that the low socioeconomic level around the school is associated with chronic levels of stress, measured through cortisol, in children and adolescents of a wide age group from 4 to 18 years old.

Despite the importance of assessing Chronic Stress, few articles have been identified that assessed stress longitudinally as far as the bibliographic review of this study has reached. Among them, the one carried out by Boardman and Alexander (2011) used data from the National Longitudinal Study on Adolescent Health to monitor the mental health of young black, white and non-Hispanic adults in the United States of America. The authors were able to identify four stress trajectories built according to the presence of stress and its decline. Among its main results, black adolescents are more likely to belong to trajectories with stress than whites, and exposure to stress was strongly associated with later depression.

In Brazilian context, the longitudinal study carried out by Correia-Zanini and Marturano (2016) evaluated the stress symptoms of children throughout the first three years of elementary school, using repeated measure analysis, that is, discriminating the changes in the mean of the whole sample of children. Without ignoring the importance of such a study, some gaps remain to be explored. One of them refers to the fact that, despite being longitudinal, the analyses performed did not discriminate between stress trajectories, that is, they do not differentiate Chronic Stress 
from Acute stress, which would be important to guide actions or identify risk groups. Another limitation concerns the need to jointly assess, in children in the early years of elementary school, variables of the child and the school context, focusing on the performance of such variables as protective or risk factors for stress, which was not addressed by the study involving trajectories carried out by Boardman and Alexander (2011).

This study is inserted in this gap, with the hypothesis that children with Chronic Stress would be more vulnerable; they would differ from those with Acute Stress or Without stress, with less academic achievement, less protective factors and more risk factors. It is also assumed that less personal resources, together with a less favorable context, may be precedent of the acute or chronic manifestation of stress in children.

This study aimed to associate groups differentiated by the trajectory of stress, in children from the 1st to the 3rd year of Elementary School - Without Stress, Acute Stress and Chronic Stress, to the variables of protection or risk of the child and the school itself.

\section{Method}

The study follows a comparison design between groups with different stress profiles.

\section{Participants}

The convenience sample consisted of 111 children (56 boys), with a mean age of 6.7 years ( $S D=0.3$ years), in the first assessment. Thirty three teachers also participated as informants. Children were divided into three groups according to the trajectories of manifestation and classification of stress, assessed in the 1st, 2nd and 3rd years, through the ESI Childhood Stress Scale (Lipp \& Lucarelli, 2008).

The Without Stress group consisted of 53 children (23 boys) whose assessments of stress symptoms indicated absence of stress or symptoms classified in the initial (alert) phase in the 1st, 2nd and 3rd year. The Acute Stress group was composed of 37 children ( 23 boys) who manifested severe symptoms of stress, that is, in the phase of Near Exhaustion or Exhaustion, in only one of the three evaluations carried out (on the 1st, 2nd, or 3rd year). The group with Chronic Stress, with 21 participants (10 boys), included children who in the three years reported symptoms classified in the ESI phase in the Near Exhaustion or in the Exhaustion phase, that is, they presented indicators of Chronic Stress. Children in other combinations of stress symptoms were not included in the study $(n=40)$. The Chi-square distribution comparison test indicated that there were no differences in the distribution of boys and girls between groups $\left(\chi^{2}(2)=3.153 ; p=0.207\right)$.

The database from which the sample comes from had as sources seven municipal elementary schools in a city in the interior of the state of São Paulo, with approximately 111 thousand inhabitants, with an HDI of 0.761 (Instituto Brasileiro de Geografia e Estatística [IBGE], 2010). At the time of the initial data collection, in 2010 , the municipal education network in that municipality had 59 1st year classes distributed in fifteen schools. The selection of the seven schools was carried out together with the municipality's education department, aiming to represent different regions, one school in the central region, two close to the center and four in more remote neighborhoods, totaling 25 classes included in the study. The participating schools obtained in 2011 between 6.1 and 7.6 in the Basic Education Development Index - IDEB (INEP, 2018).

\section{Instruments}

\section{Variable considered for group formation:}

Childhood Stress Scale - ESI (Lipp \& Lucarelli, 2008). It aims to identify the frequency with which children aged 6 to 14 experience symptoms of stress, as reported by themselves. It consists of 35 items of the Likert type from 0 to 4 points. The instrument provides, among other measures, a total score, obtained from the sum of the responses to the 35 items and also the evolution of symptoms presented in four phases, based on the score obtained by the child; being considered Without Stress up to 39 points, alert from 39.6 to 59.4 points, resistance, from 59.5 to 79.4 points, almost exhaustion, from 79.5 to 99.3 , or seven items evaluated with four points, or exhaustion, above 99.3 points. The classifications obtained in the 1st, 2nd and 3rd years were used in this study to include participants in the groups. The instrument in its original version showed good reliability, with Cronbach's alpha of 0.90 . In this study, the alpha values found were 0.88 in the 1 st year, 0.87 in the 2 nd and 0.89 in the 3 rd year.

\section{Child variables:}

Provinha Brasil 2009 (INEP, 2009). It is an assessment prepared by the National Institute of Educational Studies and Research Anísio Teixeira - INEP and aims to diagnose the literacy level of children enrolled in the 2nd year of PE. It consists of an example question to teach students how to answer the test and 24 other multiple-choice questions to assess performance. Performance evaluation questions are arranged in an increasing order of skill requirements, from the most basic to the most advanced. Each question solved correctly corresponds to one point. In this study, the test was expanded with the inclusion of five more questions suitable for the 3rd year.

Inventory of School Stressors - IEE (Trivellato-Ferreira \& Marturano, 2008). It aims to investigate disturbing or irritating situations related to school life, in four domains: school performance, family-school relationship, relationship with peers and other demands of school life. For each situation presented, the child responds if that happened to him/her during the school year; if it happened, it also informs how much the situation upset him/her - nothing, a little, more or 
less or a lot. In this investigation, the two-component structure identified by exploratory and confirmatory factor analysis in the original sample ( $n=151)$ was used, involving tensions related to the student role $\left(\alpha_{1 \text { st year }}=0.69 ; \alpha_{\text {3rd year }}=0.66\right)$ and interpersonal relationships $\left(\alpha_{1 \text { st year }}=0.71 ; \alpha_{\text {3rd year }}=0.62\right)$.

Social Skills Assessment System - SSRS-BR - Version for teachers (Freitas \& Del Prette, 2015), included for assessing Social Skills and Behavior Problems. The items that made up the scales were derived from Confirmatory Factor Analysis with the research sample, which maintained the original structure of Social Skills in five subscales: cooperation with peers (3 items), positive assertion (7 items), responsibility/ cooperation (7 items), self-defense ( 3 items), self-control ( 8 items). The sum of the 28 items of the subscales made up the variable Social Ability, used currently with satisfactory internal consistency $\left(\alpha{ }_{1 \text { st year }}=0.69 ; \alpha_{\text {3rd year }}=0.66\right)$. The Behavior Problems scale also had its structure maintained in two subscales: internalizing behavior ( 5 items) with values of $\alpha_{\text {1st year }}=0.79, \alpha_{\text {3rd year }}=0.75$; externalizing behaviors ( 7 items) with values of $\alpha_{1 \text { st year }}=0.89, \alpha_{\text {3rd year }}=0.91$.

\section{Variables of the school context based on documentary} analysis:

Early Childhood Education - ECE. Information on ECE attendance was obtained by consulting the children's enrollment record on the website of the São Paulo State Data Processing Company, with the assistance of an authorized school secretary. Two categories were created for this variable: one year of ECE $(n=11)$, two years of $\operatorname{ECE}(n=100)$.

Basic Education Development Index - IDEB. Created by INEP with the purpose of evaluating and establishing goals for Brazilian basic education. Its calculation is based on the school's approval rate, provided by the School Census, and on the average performance of students in the evaluations promoted by INEP, in the case of municipal schools, Prova Brasil. The resulting value ranges from zero to ten. Schools with values above six are considered of quality (INEP, 2018). Consultation with IDEB 2009 was carried out on the website http://portalideb.inep.gov.br.

Location. It was obtained with the help of Google Maps, having the city center as a reference point. Schools were classified into two categories, according to their location in the municipality: Central or close to the center, as they are located less than $2 \mathrm{~km}$ from the center, with three schools meeting this criterion $(n=41)$, and located in the periphery, with a distance greater than $2 \mathrm{~km}$ from the center $(=70)$.

\section{Procedure}

Data collection. Data collection started after obtaining the consent and occurred in the second academic semester of 2010, 2011 and 2012. The Child Stress Scale and the School Stress Inventory were applied, individually, during class hours and in spaces provided by schools. Provinha Brasil was applied in groups of 5 to 20 children, by the first author with the help of an assistant. The teachers in the same period responded to the SSRS, delivered in a meeting and collected on a previously agreed date.

Data analysis. For data analysis, the program SPSS version 19 was used. The assumption of normal distribution of variables in the groups was verified through the values of kurtosis and symmetry (Marôco, 2011). One-Way ANOVA was used to compare the groups, with the Bonferroni comparison between pairs, when the variables met the assumptions for parametric analysis. For the evaluation of the magnitude of differences, the effect was considered as small when $\eta^{2}{ }_{p} \leq 0.05$; medium, when $\eta^{2}{ }_{p}$ ranged from 0.051 to 0.25 ; high for $\eta^{2}$ between 0.26 and 0.50 ; and very high when $\eta_{\mathrm{p}}^{2}>0.50$ (Cohen, 1992).

The distribution analysis for two categorical variables was performed using the Chi-square test. The prediction of the different trajectories obtained was made using Multinomial Logistic Regression, with the Enter method, considering the Without Stress group as the reference category. In all statistical tests, the $95 \%$ confidence level was adopted.

\section{Ethical Considerations}

This research is part of a project approved by the Research Ethics Committee of the Faculdade de Filosofia, Ciências e Letras de Ribeirão Preto - USP (Process No. 528 / 2010.1.1794.59.2), which meets the standards set out in Resolution No. 466/12 and 510/16 of the National Health Council and the provisions of Resolution No. 016/2000 of the Federal Council of Psychology. Adult participants signed the Informed Consent Form - ICF; in the case of a child participant, one of the guardians signed the consent form and the child participant gave his/her consent.

\section{Results}

Table 1 shows the results of comparisons between trajectories, regarding the variables of the child evaluated in the 3 rd year.

The Without Stress group, compared to the others, obtained a higher average of academic performance and social skills, as well as less externalization. The group with Acute Stress presented better academic performance than the group with Chronic Stress; on the other hand, the latter perceived the school context as more stressful, in terms of tensions related to the student's role and interpersonal relationships. In all significant differences, the effect size found was of medium magnitude, varying between 0.11 in Social Skills and 0.22 in academic performance.

Table 2 shows the results for the Multinominal Logistic Regression, estimating the probability of belonging to the Chronic and Acute Stress group in relation to the Group Without Stress, considered as a reference, according to the child's variables, evaluated in the 1st year, and the school context. 
Table 1

Group comparisons regarding variables related to children $(n=111)$

\begin{tabular}{|c|c|c|c|c|c|c|c|c|}
\hline \multirow[t]{2}{*}{ Variable } & \multicolumn{2}{|c|}{$\begin{array}{l}\text { Without stress } \\
\quad(n=53)\end{array}$} & \multicolumn{2}{|c|}{$\begin{array}{c}\text { Acute Stress } \\
(n=37)\end{array}$} & \multicolumn{2}{|c|}{$\begin{array}{c}\text { Chronic Stress } \\
(n=21)\end{array}$} & \multirow[t]{2}{*}{$F(2.108)$} & \multirow{2}{*}{$\eta_{p}^{2}$} \\
\hline & Average & $S D$ & Average & $S D$ & Average & $S D$ & & \\
\hline Academic Performance & $24.7^{\mathrm{c}}$ & 3.5 & $22.2^{\mathrm{b}}$ & 4.4 & $19.1^{\mathrm{a}}$ & 4.7 & $14.9^{* * *}$ & 0.22 \\
\hline Social Skills & $40.1^{b}$ & 1.5 & $34.2^{\mathrm{a}}$ & 1.7 & $30.7^{\mathrm{a}}$ & 1.4 & $6.6^{* *}$ & 0.11 \\
\hline Externalization & $2.7^{\mathrm{a}}$ & 3.1 & $4.9^{\mathrm{b}}$ & 4.0 & $7.0^{\mathrm{b}}$ & 3.5 & $12.6^{* * *}$ & 0.19 \\
\hline Internalization & 2.2 & 2.5 & 2.9 & 2.3 & 3.1 & 2.4 & 1.8 & 0.03 \\
\hline Tensions related to student's role & $9.4^{\mathrm{a}}$ & 5.5 & $11.2^{\mathrm{a}}$ & 6.9 & $17.4^{\mathrm{b}}$ & 7.7 & $11.7^{* * *}$ & 0.18 \\
\hline Tensions in interpersonal relationships & $7.8^{\mathrm{a}}$ & 5.5 & $8.0^{\mathrm{a}}$ & 5.3 & $13.1^{\mathrm{b}}$ & 7.2 & $7.0^{* *}$ & 0.12 \\
\hline
\end{tabular}

Note. Different letters indicate differences between the averages in the Post Hoc comparisons (Bonferroni); $S D=$ standard deviation; $F=$ ANOVA statistics; $\eta_{\mathrm{p}}^{2}=$ Effect size; ${ }^{*} p \leq 0.05 ;{ }^{* *} p \leq 0.01 ;{ }^{* * *} p<0.001$.

Table 2

Significant coefficients of the logistic regression model of the Chronic Stress group, in relation to the Without Stress group, as a function of 1 st year variables, for the total sample $(n=111)$

\begin{tabular}{|c|c|c|c|c|c|c|c|c|c|}
\hline \multirow{2}{*}{ Group } & \multirow{2}{*}{ Variables } & \multirow{2}{*}{ B } & \multirow{2}{*}{ S.E. } & \multirow{2}{*}{ Wald } & \multirow{2}{*}{$d f$} & \multirow{2}{*}{$p$} & \multirow{2}{*}{$\operatorname{Exp}(B)$} & \multicolumn{2}{|c|}{$95 \%$ CI for $\operatorname{Exp}(B)$} \\
\hline & & & & & & & & Lower & Higher \\
\hline \multirow[t]{2}{*}{ Acute Stress } & $\begin{array}{l}\text { Tensions in interpersonal } \\
\text { relationships }\end{array}$ & 0.09 & 0.04 & 4.41 & 1.00 & 0.04 & 1.09 & 1.01 & 1.19 \\
\hline & Location (center or nearby) & -1.88 & 0.94 & 4.01 & 1.00 & 0.04 & 0.15 & 0.02 & 0.96 \\
\hline \multirow{3}{*}{ Chronic Stress } & Externalization & 0.10 & 0.05 & 3.71 & 1.00 & 0.05 & 1.11 & 0.99 & 1.23 \\
\hline & Tensions related to student's role & 0.27 & 0.14 & 3.83 & 1.00 & 0.05 & 1.31 & 1.00 & 1.72 \\
\hline & $\begin{array}{l}\text { Early Childhood Education } \\
\text { (attending one year) }\end{array}$ & 2.95 & 1.09 & 7.36 & 1.00 & 0.01 & 19.02 & 2.27 & 159.69 \\
\hline
\end{tabular}

Note. $\mathrm{B}=$ Non-standardized estimate; $S E=$ standardized error; $d f=$ degree of freedom; $p=$ value of statistical significance; $\operatorname{Exp}(B)=$ Standardized estimate; $\mathrm{CI}=$ Confidence Interval.

The model was significant $\left(G^{2}(18)=69.170 ; p<0.001\right)$ with a percentage of $69.8 \%$ correct total classification. The transition from the reference group (Without Stress) to the Group Acute Stress was significantly predicted by the school location (center or close to the center), with significant and negative impact $(b=-1.88 ; p=0.04)$, followed by tensions in interpersonal relationships $(\mathrm{b}=0.09 ; p=0.04)$, with a positive effect. The trajectory of Chronic Stress was positively affected, in increasing order of impact, by externalization $(\mathrm{b}=0.10 ; p=0.05)$, by tensions related to the student role $(\mathrm{b}=0.27 ; p=0.05)$, and for having only one year of Early Childhood Education $(b=2.95 ; p=0.01)$. The variables, academic performance, social skills, internalization, tensions in interpersonal relationships, IDEB and school location, which were part of the tested model, were not significant.

\section{Discussion}

This study aimed to associate groups differentiated by the trajectory of stress, in children from the 1st to the 3rd year of Elementary School - Without Stress, Acute Stress and Chronic Stress, to the variables of protection or risk of the child and the school itself. To this end, a procedure was outlined that qualitatively differentiated three specific trajectories in terms of the occurrence and duration of stress symptoms, namely, Without Stress, with Acute Stress and with Chronic Stress, in the expectation of verifying the differential effect of stress over the first years of elementary school on children's characteristics and to identify which variables act as precedent protection or risk for these specific stress trajectories.

It is considered that this objective was achieved, as it was possible to characterize different profiles of stress trajectories regarding the variables of the children and the context. The group with Chronic Stress was identified as the most vulnerable, as it is exposed to a wide range of risks related to the child and to the more adverse school context; on the other hand, the Without Stress group proved to be more protected regarding these variables. It is also noteworthy that the group with Acute Stress fluctuated in terms of the child's characteristics and the context, showing similarities and differences in relation to the other groups. 
In the comparisons, the Without Stress group had higher averages than the Acute Stress and Chronic Stress groups in performance and social skills indicators, as well as having less behavior problems. Students with Acute Stress were similar to those with Chronic Stress in social skills, externalization and internalization, but showed better results in academic performance, as well as in tensions related to the student's role and interpersonal relationships. Children with Acute Stress trajectories showed similar values to the group Without Stress in the two factors related to the perception of school stressors.

Such results corroborate the regression, which indicated the shorter length of stay in Early Childhood Education (having attended one year) and externalization as predictive of the increased chance of the child having Chronic Stress, by reference to the group without stress. The perception of school stressors in the 1st year proved to be variant, since the one focused on the tensions related to the student's role stood out for positively predicting the chance of belonging to the group with Chronic Stress, while the perception of tensions in interpersonal relationships was a predictor of Acute Stress trajectories. The school location was also predictive for the latter group.

The set of results suggests that risk variables referring to the child and the context may contribute to the manifestation and chronicity of stress symptoms in schoolchildren, and that different trajectories of stress are associated with impairment in the academic, interpersonal and/or behavioral domains. Therefore, school and good school experiences are important to protect children from stress.

It is worth mentioning that contextual indicators, such as Early Childhood Education and the school location, as well as the perception of stressors, can be considered as latent measures, since they contemplate direct or mediated relationships of other important variables, such as, for example, socioeconomic level of the family and school students, cultural values, interpersonal relationships, among others, thus endorsing the importance of this context in the 1 st year for the stress symptoms.

When analyzing the data obtained regarding the losses in performance indicators, in groups with Chronic and Acute Stress trajectories, there is little support in previous studies, given that the proposal of stress trajectories is an original methodological contribution of this research. Although the cited literature has given basis to the hypothesis that there would be an association of stress symptoms and low performance (Crepaldi et al., 2017; Fernández-Martín et al., 2015; Trivellato-Ferreira \& Marturano, 2008), such studies do not consider different trajectories for stress. In this investigation, while academic performance in the 1 st year was not a significant predictor of stress trajectories, it determined the three trajectories in the 3rd year, being higher for the group Without Stress and worse for the group with Chronic Stress. Although the research design does not support interpretations of cause and effect, we can speculate about the precedence of stress over academic difficulties, or, more likely, about transactional feedback processes with cumulative results over time.

The relationships found between symptoms of stress and social skills were different. Social skills in the 1st year did not predict trajectories with stress but were associated, in the 3 rd year, with the absence of stress symptoms. The negative association between social skills and stress confirms findings from studies on the same age group that found associations between social skills and stress (Crepaldi et al., 2017; Sbaraini \& Scherman, 2008; Oberle, 2018).

Regarding externalizing and internalizing behavior problems and the perception of school stressors, they were expected to be more present in groups with stress symptoms, which was found, with the exception of internalization, converging with the studies carried out with samples of similar age groups (Crepaldi et al., 2017; Stasiak \& Weber, 2013). The externalization presented by the students in the 1 st year was a predictor of both Acute and Chronic Stress.

No comparable empirical studies were identified in the literature in terms of sample and method that considered internalization as associated with child stress. In the study conducted by Crepaldi et al. (2017), boys with stress showed more internalization than boys without stress. In the study by Yuan et al. (2017) the association between internalization and stress was verified, but for participants whose age ranged from 7 to 19 years. And in the study by Cairney et al. (2013) that dealt with the presentation of a model, the authors indicated that exposure to stressors may be associated with more internalization in children with motor problems. Such differences in terms of sample and method may be responsible for the inconsistency between the findings, therefore, it is still a gap to be explored by future studies.

The perception of school stressors proved to be relevant in differentiating stress symptom trajectories. Children with chronic stress trajectories differed from other groups because they perceived their school routine as more stressful in the 3rd year, both in the academic sphere and in interpersonal relationships. Given that, by definition, trajectories of chronic stress imply high stress in the 3rd year, these results converge with those of studies that investigated contemporary associations between stress symptoms and perception of school stressors, evaluated globally (Trivellato-Ferreira \& Marturano, 2008) or with the distinction between tensions related to the student's role and in interpersonal relationships (Crepaldi et al., 2017)

The perception of school stressors corresponds to the child's assessment of stressful situations that happen in his/her school and, therefore, can be considered an indicator of the level of demand of the stressor source for the child. The prediction results of the trajectories, based on variables evaluated in the 1st year, bring an original contribution by suggesting relations of precedence of such tensions over chronic or acute stress trajectories. Byrne et al. (2011) had already pointed out, in children of the same age group, significant correlations between the intensity of school 
tensions reported by the children and symptoms of state anxiety and depression 24 months later. Our results add specificity to these relationships, pointing out specific links between domains of environmental stress and the course of symptoms. They also show consistency between children's perceptions and independent environmental predictors in the final regression models. Thus, the risk for acute stress trajectories was increased by tensions in interpersonal relationships and decreased by a presumably safer school context, from central schools or close to the center. And the risk for chronic stress trajectories was intensified by early tensions related to the student's role, which signal academic difficulties, as well as by less access to early childhood education, also inversely related to school performance (Trivellato-Ferreira \& Marturano, 2008).

In terms of context, it was expected that having attended early childhood education for two years would be a protective factor for stress, along with the greater IDEB, while studying in schools located on the periphery would be a risk factor, as suggested by the study performed by Vliegenthart et al. (2016), which corroborated, with the exception of IDEB, that was not a significant predictor of trajectories. It is worth mentioning that all schools in the year of assessment had reached grade six or close to six in IDEB, therefore being considered as of quality according to INEP (2018).

In terms of design, this study contributed to a qualitative proposal considering data obtained from trajectories of stress assessments over time, as proposed by Boardman and Alexander (2011). Thus, it advances in relation to the study of trajectories through modal trends (Correia-Zanini \& Marturano, 2016). In this sense, although with similar samples, it is difficult to compare the data from this study with that of the referred studies, since the configuration of the groups meets different criteria.

The study investigated a relevant set of personal and context variables obtained through various informants: child, teacher, institutional indicators, however, an important context was not evaluated, which is the familiar one, and, therefore, the indication of that in later research can be evaluated, since conditions of the family context are recognized as fundamental for the development of schoolchildren. It is also suggested to include, in a future research model, variables related to coping strategies of children in the face of stressful situations in the school context, differentiating them from the coping results, as suggested by the integrative study by Ramos, Enumo and Paula (2015).

A point to be highlighted as a limit is that the groups were not homogeneous in terms of number of participants, although measures of effect size helped to interpret the statistical significance obtained. In any case, it is considered that this study contributed to fill important gaps by offering a methodological model for investigating stress in schoolchildren from a transactional perspective in order to explore the importance of individual and contextual characteristics that may be useful in the promotion, prevention and intervention of stress in psychology.

\section{References}

Almeida, L. C. (2017). As desigualdades e o trabalho das escolas: Problematizando a relação entre desempenho e localização socioespacial [Inequalities and schools' work: Discussing the relationship between achievment and socioespacial location]. Revista Brasileira de Educação, 22(69), 361-384. doi:10.1590/s1413-24782017226919

Boardman, J.D., \&Alexander, K. B. (2011). Stress trajectories, health behaviors, and the mental health of black and white young adults. Social Science \& Medicine, 72(10), 1659-1666. doi:10.1016/j.socscimed.2011.03.024

Byrne, D. G., Thomas, K. A., Burchell, J. L., Olive, L. S., \& Mirabito, N. S. (2011). Stressor experience in primary school-aged children: Development of a scale to assess profiles of exposure and effects on psychological wellbeing. International Journal of Stress Management, 18(1), 88-111. doi:10.1037/a0021577

Cairney, J., Rigoli, D., \& Piek, J. (2013). Developmental coordination disorder and internalizing problems in children: The environmental stress hypothesis elaborated. Developmental Review, 33(3), 224-238. doi:10.1016/j.dr.2013.07.002

Cohen, J. (1992). A power primer. Psychological Bulletin, $112(1), 155-159$.

Correia-Zanini, M. R. G., \& Marturano, E. M. (2016). Getting started in elementary school: Cognitive competence, social skills, behavior, and stress. Psico-USF, 21(2), 305-317. doi: $10.1590 / 1413-82712016210208$

Crepaldi, E. T. S., Correia-Zanini, M. R. G., \& Marturano, E. M. (2017). Elementary school entry: Stress, competence and adjustment in first grade students. Temas em Psicologia, 25(2), 503-515. doi:10.9788/TP2017.2-06Pt

Escobar, M., Alarcón, R., Blanca, M. J., Fernández-Baena, F. J., Rosel, J. F., \& Trianes, M. V.(2013). Daily stressors in schoolage children: A multilevel approach. School Psychology Quartely, 28(3), 227-238. doi:10.1037/spq0000020

Fernández-Martín, E., Trianes-Torres, M. V., MaldonadoMontero, E. F., Miranda-Páez, J., Ortíz, C., \& Engüix, A. (2015). Psychological and psychobiological stress in the relationship between basic cognitive function and school performance. Anales de Psicología, 31(1), 120-126. doi:10.6018/analesps.31.1.151451

Freitas, L. C., \& Del Prette, Z. A. P. (2015). Social skills rating system - Brazilian version: New exploratory and confirmatory factorial analyses. Avances en Psicología Latinoamericana, 33(1), 135-156. doi:10.12804/ ap133.01.2015.10

Instituto Brasileiro de Geografia e Estatística. (2010). Índice de Desenvolvimento Humano [Human Development Index]. Retrieved from https://cidades.ibge.gov.br/brasil/ $\mathrm{sp} /$ pesquisa/37/30255 
Instituto Nacional de Estudos e Pesquisas Educacionais Anísio Teixeira. (2009). Provinha Brasil: 20 semester 2009: Caderno do aluno [Provinha Brasil: $2^{\text {nd }}$ semester 2009: Student notebook]. Retrieved from http:// download.inep.gov.br/educacao_basica/provinha_brasil/ kit/2009/2_semestre/caderno_do_aluno_2_2009.pdf

Instituto Nacional de Estudos e Pesquisa Educacionais Anísio Teixeira. (2018). Nota técnica: Índice de Desenvolvimento da Educação Básica - Ideb [Technical note: Basic Education Developmental Index]. Retrieved from http://download.inep.gov.br/educacao_basica/ portal_ideb/o_que_e_o_ideb/Nota_Tecnica_n1_ concepcaoIDEB.pdf

Kaplan, D. S., Liu, R. X., \& Kaplan, H. B. (2005). School related stress in early adolescence and academic performance three years later: The conditional influence of self expectations. Social Psychology of Education, 8, 3-17. doi:10.1007/s11218-004-3129-5

Lipp, M. E. N. (2014). O diagnóstico do stress em crianças [The diagnosis of stress in children]. In: M. Lipp (Org.). Stress em crianças e adolescents [Stress in children and adolescents] (pp. 17-40). Campinas, SP: Papirus.

Hoffman, L. W. (1979). Experiência da primeira infância e realizações femininas [Early childhood experience and female achievements]. In H. Bee (Org.), Psicologia do desenvolvimento: Questões sociais [Developmental psychology: Social issues] (pp. 45-65). Rio de Janeiro, RJ: Interamericana.

Lipp, M. E. N., \& Lucarelli, M. D. M. (2008). Escala de Stress Infantil (ESI): Manual [Child Stress Scale (ESI): Manual]. São Paulo, SP: Casa do Psicólogo.

Liu, Y., \& Lu, Z. (2011). Longitudinal analysis of Chinese high school student's stress in school and academic achievement. Educational Psychology, 31(6), 723-729. doi:10.1080/01443410.2011.600245

Marôco, J. (2011). Análise estatística com o SPSS statistics [Statistical analysis with SPSS statistics] (5th ed.). Pero Pinheiro, Portugal: ReportNumber.

Oberle, E. (2018). Social-emotional competence and early adolescents' peer acceptance in school: Examining the role of afternoon cortisol. PloS One, 13(2), e0192639. doi:10.1371/journal.pone.0192639

Reppold, C. T., Pacheco, J., Bardagi, M., \& Hutz, C. S. (2002). Prevenção de problemas de comportamento e desenvolvimento de competências psicossociais em crianças e adolescentes: Uma análise das práticas educativas e estilos parentais. In C. S. Hutz (Org.), Situações de risco e vulnerabilidade na infância e na adolescência: Aspectos teóricos e estratégias de intervenção [Situations of risk and vulnerability in childhood and adolescence: Theorical aspects and intervention strategies] (pp. 7-52). São Paulo, SP: Casa do Psicólogo.
Romanholo, R. A., Theodoro, W. W. G., Baia, F. C., Pereira, J. E., Lucena, A. R. N., Prestes, J., \& Almeida, F. M. (2017). Estresse infantil e sua relação com o rendimento escolar da criança nas disciplinas de português e matemática [Child stress and its relationship with childhood performance in portuguese disciplines and mathematics]. Revista de Saúde e Ciências Biológicas, 5(2), 155-159. doi:10.12662/2317-3076jhbs.v5i2.1129. p155-159.2017

Ramos, F. P., Enumo, S. R. F., \& Paula, K. M. P. (2015). Teoria motivacional do Coping: Uma proposta desenvolvimentista de análise do enfrentamento do estresse [Motivational theory of Coping: A developmental proposal for the analysis of coping with stress]. Estudos de Psicologia (Campinas), 32(2), 269-279. doi:10.1590/0103-166X2015000200011

Sbaraini, C. R., \& Schermann, L. B. (2008). Prevalence of childhood stress and associated factors: A study of schoolchildren in a city in Rio Grande do Sul state, Brazil. Cadernos de Saúde Pública, 24(5), 1082-1088. doi:10.1590/S0102-311X2008000500015

Stasiak, G. R., \& Weber, L. N. D. (2013). Percepção do estresse pelas crianças do primeiro ano do ensino fundamental [Stress perceived by children from first grade of elementary school]. Impulso, 23(56), 35-45. doi:10.15600/2236-9767/impulso.v23n56p35-45

Trivellato-Ferreira, M. C., \& Marturano, E. M. (2008). Recursos da criança, da família e da escola predizem competência na transição da $1^{a}$ série [Child, family and school resources predict competence in the transition form 1st grade]. Revista Interamericana de Psicología, 42(3), 549-558. Retrieved from http://pepsic.bvsalud. org/pdf/rip/v42n3/v42n3a15.pdf

Vliegenthart, J., Noppe, G., van Rossum, E. F. C., Koper, J. W., Raat, H., \& van den Akker, E. L. T. (2016). Socioeconomic status in children is associated with hair cortisol levels as a biological measure of chronic stress. Psychoneuroendocrinology, 65, 9-14. doi:10.1016/j.psyneuen.2015.11.022

Yuan, W., Zhang, L.-F., \& Fu, M. (2017). Thinking styles and academic stress coping among Chinese secondary school students. Educational Psychology, 37(8), 1015-1025. doi:10.1080/01443410.2017.1287343

Marta Regina Gonçalves Correia-Zanini is a Professor of the Centro Universitário das Faculdades Associadas de Ensino, São João da Boa Vista-SP, Brazil.

Sonia Regina Loureiro is a Professor of the Universidade de São Paulo, Ribeirão Preto-SP, Brazil.

Edna Maria Marturano is a Professor of the Universidade de São Paulo, Ribeirão Preto-SP, Brazil. 
Authors' Contribution:

All authors made substantial contributions to the conception and design of this study, to data analysis and interpretation, and to the manuscript revision and approval of the final version. All the authors assume public responsability for content of the manuscript.

Received: Oct. 08, 2018

1st Revision: Mar. 19, 2019

Approved: Apr. 25, 2019

How to cite this article:

Correia-Zanini, M. R. G., Loureiro, S. R., \& Marturano, E. M. (2020). Protection and risk for different school stress trajectories. Paidéia (Ribeirão Preto), 30, e3026.doi:https://doi.org/10.1590/1982-4327e3026 